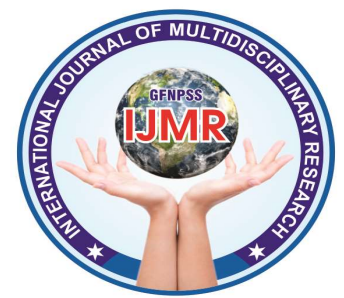

\title{
A STUDY TO ASSESS EFFECTIVENESS OF VIDEO ASSISTED LEARNING ON \\ KNOWLEDGE \& PRACTICE OF HEALTH CARE PROFESSIONALS \\ REGARDING BIOMEDICAL WASTE MANAGEMENT IN TERTIARY CARE \\ HOSPITAL WESTERN RAJASTHAN
}

HIMANSHU ${ }^{1}$ NARENDRA PAL SINGH CHOUDHARY ${ }^{2}$

${ }^{1}$ Nursing officer, Govt of Rajasthan

\section{${ }^{2}$ H.O.D. Department of Community Health Nursing Govt. College of Nursing Jodhpur \\ Corresponding Email: aspiranthimanshu92@gmail.com}

\begin{abstract}
Introduction: Great strides have been made in the field of health care system over the years. The health of public and professionals alike are affected by poor waste management practices and also contributes to environmental degradation.
\end{abstract}

Material \&Methods: Pre experimental approach for the study. One group pre-test post-test design (O1 X O2) was adopted for the study the sample consisted of 60 Health Care Professionals. The setting of the study was Umaid Hospital Jodhpur. The sampling technique was convenience sampling.

Results :The mean of knowledge regarding biomedical waste management was 23 good ,33 average and 4 poor in pre-test was increased to 55 good, 5 average and 0 poor in the post test. Practice regarding biomedical waste management was 10 good, 22 averages and 28 poor in pre-test was increased to 21 good, 31 average and 8 poor in the post test. The finding revealed that there was improvement in the mean percentage of post test score compared to mean percentage of pre-test score.

Conclusion: the present study that knowledge and practice awareness about the biomedical waste generation hazards, legislation and management among health care professionals in tertiary care centre, western Rajasthan, were not satisfactory.

Keywords: Bio-medical waste, Waste management, Effectiveness, Video assisted learning, Knowledge, Practice, Health care professionals.

\begin{tabular}{ccc}
\hline Received & Accepted & Available online \\
\hline $21 / 09 / 2021$ & $26 / 09 / 2021$ & $03 / 10 / 2021$ \\
\hline
\end{tabular}




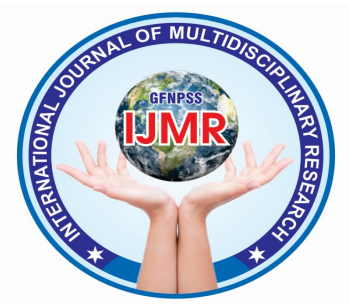

Let the wastes of "the sick" not contaminate the lives of

\section{"The Healthy" - K.PARK \\ INTRODUCTION :}

The term "Biomedical waste" has been defined as any waste, which is generated during the diagnosis, treatment or immunization of human beings or animals, or in research activities pertaining thereto, or in the production or testing of biological.

Government of India's Bio Medical Waste (Management and Handling) Rules 1998, which amended in 2000, 2003, 2016 and 2018.

In India, the Ministry of Environmental and forests has promulgated the Bio Medical Waste (Management and Handling) Rules 1998 which was first amended in 2000 and latest amendment in 2018 for proper management Bio Medical Waste.These rules are under The ENVIRONMENT PROTECTION ACT 1986 (29 of 1986). These rules are mean to improve the overall waste management of health care facilities in India. The absence of proper waste management, lack of awareness about the health hazards from Bio Medical Waste insufficient financial and human resources, and poor control of waste disposal are the most critical problems connected with health care waste.
DrMadhviSanwalka, Dr Grace John, et.al. (2020) ${ }^{17}$ A Study conducted of Bio medical waste management. Sample size consists of 150 healthcare personnel. The result from the present study, the result show revealed the major findings of the study were; with the respect to the overall status of the healthcare personnel, it's evident that majority $\mathrm{We}$ found out that technicians $(89.95 \%)$ and nurses $(88.87 \%)$ have more knowledge regarding $\mathrm{BIO}$ MEDICAL WASTEM then doctors $(85.82$ $\%)$. But doctors $(82.20 \%)$ are more aware for proper management than nurses $(73.80 \%)$ and technicians (64.0\%). Doctors $(80.87 \%)$ and nurses $(82 \%)$ are practicing these norms more than technicians $(59 \%)$.

Dhasarathi Kumar, et.al. ${ }^{18}$ (2018) A Study conducted on Knowledge Level on Bio-Medical Waste Management Sample size consists of 100 staff nurses working in selected hospital. The result from the present study, the result show revealed the major findings of the study were; with the respect to the overall status of the staff nurses, it's evident that majority $75 \%$ of the subject had inadequate $25 \%$ had moderate knowledge and none of the nurses have adequate knowledge. 


\section{MATERIAL \& METHODS}

Research Approach: In order to accomplish the objective of the study, a quantitative research approach was considered in this study.

Research Design: For the present study, a pre-experimental design adopted. A preexperimental research design was used to assess the knowledge and practice of health care professionals.

\section{Research Setting of Study:-}

This study will be conducted in health care professionals in departments under Dr. S.N medical college of nursing Jodhpur.

\section{RESEARCH POPULATION:}

In this study population is all Health care professionals at Jodhpur.

\section{SAMPLING TECHNIQUE:}

This research study will adopt nonprobability convenience sampling technique for selecting sample.

\section{SAMPLE SIZE:}

In this study, the sample consists of 60 Health Care Professionals departments under Dr. S.N medical college Jodhpur.

\section{METHOD OF DATA COLLECTION}

The data will be collected from Health Care Professionals through the Structured questionnaire method by structured standardized tool in departments under Dr.

S.N medical college jodhpur.

RESULT

PART-I SOCIO-DEMOGRAPHIC CHARACTERISTIC OF THE SAMPLES

Table No. 1: Frequency and percentage

distribution of socio-demographic

characteristic of the samples.

$(\mathrm{N}=\mathbf{6 0})$

\begin{tabular}{|c|c|c|}
\hline $\begin{array}{c}\text { Socio- } \\
\text { Demographic } \\
\text { Characteristic }\end{array}$ & Frequency(n) & $\begin{array}{l}\text { Percentage } \\
\quad(\%)\end{array}$ \\
\hline \multicolumn{3}{|l|}{ Age (in years) } \\
\hline $20-30$ & 20 & $33.33 \%$ \\
\hline $30-40$ & 17 & $28.33 \%$ \\
\hline $40-50$ & 8 & $13.33 \%$ \\
\hline $\begin{array}{l}50 \text { years and } \\
\text { above }\end{array}$ & 15 & $25.00 \%$ \\
\hline \multicolumn{3}{|l|}{ Religion } \\
\hline Hindu & 44 & $73.30 \%$ \\
\hline Muslim & 10 & $16.70 \%$ \\
\hline Christian & 5 & $8.30 \%$ \\
\hline Others & 1 & $1.70 \%$ \\
\hline \multicolumn{3}{|c|}{ Professional Qualification } \\
\hline A.N.M & 2 & $3.30 \%$ \\
\hline G.N.M & 55 & $91.70 \%$ \\
\hline $\begin{array}{l}\text { Graduate } \\
\text { Nursing }\end{array}$ & 3 & $5.00 \%$ \\
\hline $\begin{array}{l}\text { Post Graduate } \\
\text { Nursing }\end{array}$ & 0 & $0.00 \%$ \\
\hline \multicolumn{3}{|c|}{ Year of experience in present jobs } \\
\hline $\begin{array}{l}\text { Less than } 1 \\
\text { year }\end{array}$ & 12 & $20.00 \%$ \\
\hline $1-5$ years & 5 & $8.30 \%$ \\
\hline $5-10$ years & 18 & $30.00 \%$ \\
\hline $\begin{array}{l}\text { More than } 10 \\
\text { years }\end{array}$ & 25 & $41.70 \%$ \\
\hline \multicolumn{3}{|c|}{$\begin{array}{l}\text { Source of Information regarding Bio medical } \\
\text { waste }\end{array}$} \\
\hline Mass media & 0 & $0.00 \%$ \\
\hline $\begin{array}{l}\text { Upgraded } \\
\text { courses }\end{array}$ & 2 & $3.30 \%$ \\
\hline $\begin{array}{l}\text { In-service } \\
\text { training }\end{array}$ & 34 & $56.70 \%$ \\
\hline Co-worker & 24 & $40.00 \%$ \\
\hline
\end{tabular}




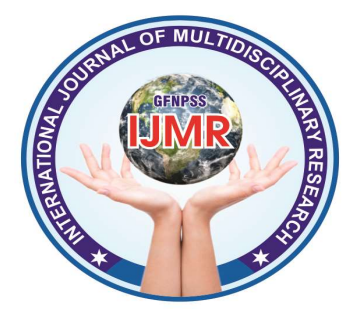

\section{PART-II}

\section{PRE-TEST KNOWLEDGE REGARDING BIO MEDICAL WASTEMANAGEMENT}

Table No. 2: Frequency and percentage distribution of the samples pre-test level of knowledge regarding Bio medical waste management.

$(\mathrm{N}=\mathbf{6 0})$

\begin{tabular}{|l|c|c|}
\hline $\begin{array}{c}\text { Level of } \\
\text { Knowledge }\end{array}$ & Frequency & Percentage \\
\hline Poor & 4 & $6.67 \%$ \\
\hline Average & 33 & $55.00 \%$ \\
\hline Good & 23 & $38.33 \%$ \\
\hline Total & 100 & $100.0 \%$ \\
\hline
\end{tabular}

Table No. 2 shows that majority $(55 \%)$ of the sample had average knowledge regarding Bio medical waste management, followed by $38.33 \%$ had good knowledge and remaining (6.67\%) samples had poor knowledge regarding Bio medical waste management.

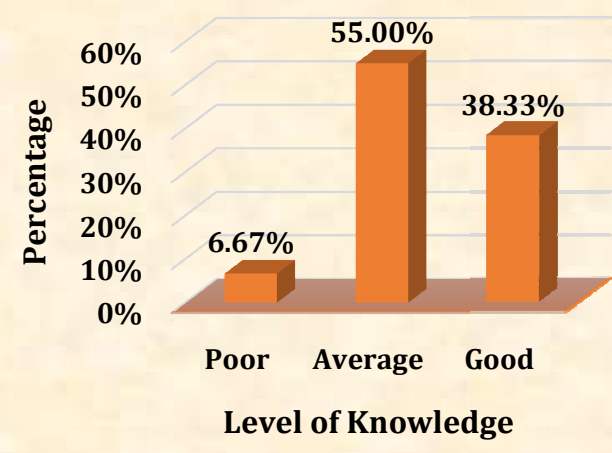

Figure No. 1: Simple Bar diagram showing the percentage distribution of the samples according to their Level of Knowledge.
Table No. 3: Aspects wise pre-test mean knowledge score regarding Bio medical waste management.

\begin{tabular}{|l|l|l|l|l|l|}
\multicolumn{9}{|c|}{$(\mathbf{N}=60)$} \\
\hline Aspects & Max & Mean & Mean \% & \pm S.D. & Median \\
\hline $\begin{array}{l}\text { General } \\
\text { information about } \\
\text { Bio medical waste }\end{array}$ & 18 & 13.92 & $77.32 \%$ & 2.47 & 14 \\
\hline $\begin{array}{l}\text { Bio medical waste } \\
\text { law }\end{array}$ & 5 & 3.58 & $71.67 \%$ & 1.21 & 4 \\
\hline $\begin{array}{l}\text { Bio medical waste } \\
\text { process }\end{array}$ & 7 & 5.15 & $73.57 \%$ & 1.85 & 6 \\
\hline Over all & 30 & 22.65 & $75.50 \%$ & 4.12 & 23 \\
\hline
\end{tabular}

Table No. 3 shows the pre-test mean knowledge score of samples according to the different Aspects of Bio medical waste. It was highest (77.32\%) regarding the 'General information about Bio medical waste' with the mean $13.92 \pm 2.47$, followed by $73.57 \%$ regarding the 'Bio medical waste process' with the mean $5.15 \pm 1.85$, and the lowest $(71.67 \%)$ regarding the 'Bio medical waste law' of Bio medical waste management. The overall pretest mean percentage knowledge score is $75.5 \%$ with the mean of $22.65 \pm 4.12$. Based on the findings we can conclude that the overall and as well as its different aspects pretest knowledge score of samples regarding Bio medical waste have been Average.

\section{PART-III}

PRE-TEST PRACTICE REGARDING BIO MEDICAL WASTEMANAGEMENT

Table No. 4: Frequency and percentage distribution of the samples pre-test level of

GFNPSS-International Journal of Multidisciplinary Research, Volume 2, Issue 9, September 2021 


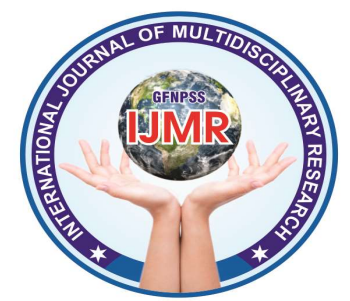

practice regarding Bio medical waste Management.

$(\mathrm{N}=60)$

\begin{tabular}{|l|c|c|}
\hline \multicolumn{1}{|c|}{$\begin{array}{c}\text { Level of } \\
\text { Practice }\end{array}$} & Frequency & Percentage \\
\hline Poor & 28 & $46.67 \%$ \\
\hline Average & 22 & $36.67 \%$ \\
\hline Good & 10 & $16.67 \%$ \\
\hline Total & 100 & $100.0 \%$ \\
\hline
\end{tabular}

Table No. 4 shows that majority $(46.67 \%)$ of the sample had poor practice regarding Bio medical waste Management, followed by $36.67 \%$ had average practice and remaining (16.67\%) samples had good practice regarding Bio medical waste Management.

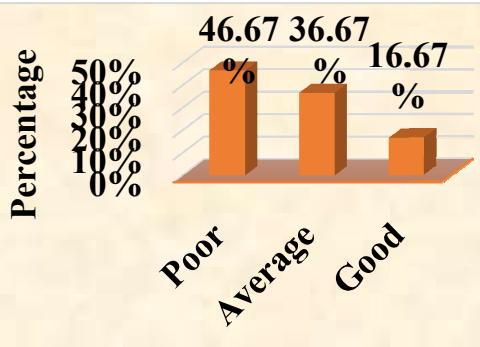

Level of Practice

Figure No. 2: Simple Bar diagram showing the percentage distribution of the samples according to their Level of Practice.

Table No. 5: Pre-test mean practice score regarding Bio medical waste Management.

$(\mathrm{N}=60)$

\begin{tabular}{|c|c|c|c|c|}
\hline Max & Mean & Mean \% & \pm S.D. & Median \\
\hline 7 & $\mathbf{3 . 8 7}$ & $\mathbf{5 5 . 2 4 \%}$ & $\mathbf{1 . 5 1}$ & 4 \\
\hline
\end{tabular}

Table No. 5 shows the pre-test mean percentage practice score is $55.24 \%$ with

the mean of $3.87 \pm 1.51$. Based on the findings we can conclude that the pre-test practice score of samples regarding Bio medical waste have been Poor.

\section{PART-IV \\ EFFECTIVENESS OF VIDEO ASSISTED LEARNING ON KNOWLEDGE}

Table No. 6: Comparison of pre-test and

post-test on level of knowledge regarding

Bio medical waste management.

$(\mathrm{N}=60)$

\begin{tabular}{|l|c|c|c|c|l|}
\hline $\begin{array}{c}\text { Level of } \\
\text { Knowledge }\end{array}$ & $\begin{array}{c}\text { Pre- } \\
\text { test }\end{array}$ & $\begin{array}{c}\text { Post- } \\
\text { test }\end{array}$ & $\begin{array}{c}\boldsymbol{x}^{\mathbf{2}} \\
\text { Value }\end{array}$ & $\boldsymbol{d f}$ & P value \\
\hline Poor & 4 & 0 & & & \\
\cline { 1 - 3 } Average & 33 & 5 & \multirow{3}{*}{37.76} & 2 & $<\mathbf{0 . 0 0 1 *}$ \\
\cline { 1 - 3 } Good & $\mathbf{2 3}$ & $\mathbf{5 5}$ & & & \\
\hline
\end{tabular}

* Significant at $\mathbf{p} \leq \mathbf{0 . 0 5}$

Table No. 6 shows that, the calculated Pearson Chi-squared value $\left(\chi_{(2)}^{2}=37.76\right)$ and its corresponding $\mathrm{p}$ value $<0.001$ is very less than 0.05 . Hence, there is very highly significant difference found in between pretest and post-test level of knowledge regarding Bio medical waste at level of significance $\mathrm{p} \leq$ 0.05 .

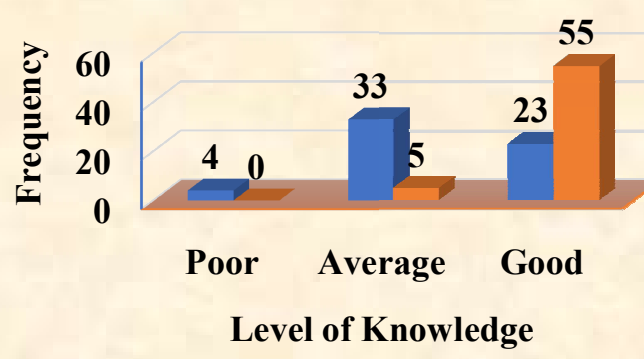

Figure No. 3: Simple Bar diagram showing the percentage distribution of the samples

GFNPSS-International Journal of Multidisciplinary Research, Volume 2, Issue 9, September 2021 


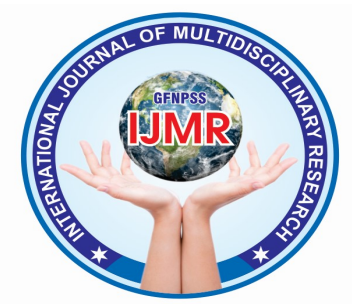

according to their Level of Knowledge.

PART-V

EFFECTIVENESS OF VIDEO ASSISTED

LEARNING ON PRACTICE

Table No. 7: Comparison of pre-test and

Table No. 8: Comparison of pre-test and

post-test knowledge score regarding Bio medical waste management.

post-test on level of practice regarding Bio medical waste Management.

$(\mathrm{N}=60)$

\begin{tabular}{|c|c|c|c|c|c|c|}
\hline & & & & & \multicolumn{2}{|c|}{$(\mathrm{N}=60)$} \\
\hline Aspects & $\begin{array}{c}\text { Max } \\
\text { Score }\end{array}$ & $\begin{array}{c}\text { Pre- } \\
\text { test } \\
\text { Mean } \\
\pm \text { SD }\end{array}$ & $\begin{array}{l}\text { Post- } \\
\text { test } \\
\text { Mean } \\
\pm \text { SD }\end{array}$ & $\begin{array}{l}\text { Knowledge } \\
\quad \text { gain } \\
\text { Mean } \pm \text { SD }\end{array}$ & $\begin{array}{l}\text { Paired } \\
\mathrm{t} \text {-value }\end{array}$ & $P$ value \\
\hline $\begin{array}{l}\text { General } \\
\text { information } \\
\text { about Bio } \\
\text { Medical } \\
\text { Waste }\end{array}$ & 18 & $\begin{array}{c}13.92 \\
\pm 2.47\end{array}$ & $\begin{array}{c}16.53 \\
\pm 1.40\end{array}$ & $2.62 \pm 2.71$ & 7.472 & $<0.001^{*}$ \\
\hline $\begin{array}{l}\text { Bio } \\
\text { medical } \\
\text { waste law }\end{array}$ & 5 & $\begin{array}{c}3.58 \pm \\
1.21\end{array}$ & $\begin{array}{c}4.27 \pm \\
0.84\end{array}$ & $0.68 \pm 1.33$ & 3.968 & $<0.001^{*}$ \\
\hline $\begin{array}{l}\text { Bio } \\
\text { medical } \\
\text { waste } \\
\text { process }\end{array}$ & 7 & $\begin{array}{c}5.15 \pm \\
1.85\end{array}$ & $\begin{array}{c}6.28 \pm \\
1.01\end{array}$ & $1.13 \pm 1.92$ & 4.578 & $<0.001^{*}$ \\
\hline Over all & 30 & $\begin{array}{c}22.65 \\
\pm \\
4.12\end{array}$ & $\begin{array}{c}27.08 \\
\pm \\
1.99\end{array}$ & $\begin{array}{c}4.43 \pm \\
3.94\end{array}$ & 8.721 & $<0.001^{*}$ \\
\hline
\end{tabular}

* Significant at $\mathbf{p} \leq \mathbf{0 . 0 5}$

Table No. 7 shows that comparison of the mean knowledge score, before and after implementation of Video Assisted Learning, the overall mean knowledge score was apparently higher in post-test $(27.08 \pm 1.99)$ with the mean difference of $4.43 \pm 3.94$ and the computed P-value for the paired t-score for overall and as well as different aspects of Bio medical waste is $<0.001$, which is very less than the 0.05 . Hence, there is a very highly significant difference found in between pretest and post-test knowledge score regarding Bio medical waste at the level of significance $\mathrm{p} \leq 0.05$.

\begin{tabular}{|l|c|c|c|c|c|}
\hline $\begin{array}{l}\text { Level of } \\
\text { Practice }\end{array}$ & $\begin{array}{c}\text { Pre- } \\
\text { test }\end{array}$ & $\begin{array}{c}\text { Post- } \\
\text { test }\end{array}$ & $\begin{array}{c}\boldsymbol{x}^{2} \\
\text { Value }\end{array}$ & $\boldsymbol{d} \boldsymbol{f}$ & P value \\
\hline Poor & 28 & 8 & & & \\
\cline { 1 - 3 } Average & 22 & 31 & \multirow{2}{*}{16.54} & 2 & $<\mathbf{0 . 0 0 1 *}$ \\
\cline { 1 - 3 } Good & $\mathbf{1 0}$ & $\mathbf{2 1}$ & & & \\
\hline
\end{tabular}

* Significant at $\mathrm{p} \leq \mathbf{0 . 0 5}$

Table No. 8 shows that, the calculated Pearson Chi-squared value $\left(\chi^{2}{ }_{(2)}=16.54\right)$ and its corresponding $p$ value $<0.001$ is very less than 0.05 . Hence, there is very highly significant difference found in between pre-test and posttest level of practice regarding Bio medical waste at level of significance $p \leq 0.05$.

Table No. 9: Comparison of pre-test and post-test practice score regarding Bio medical waste Management.

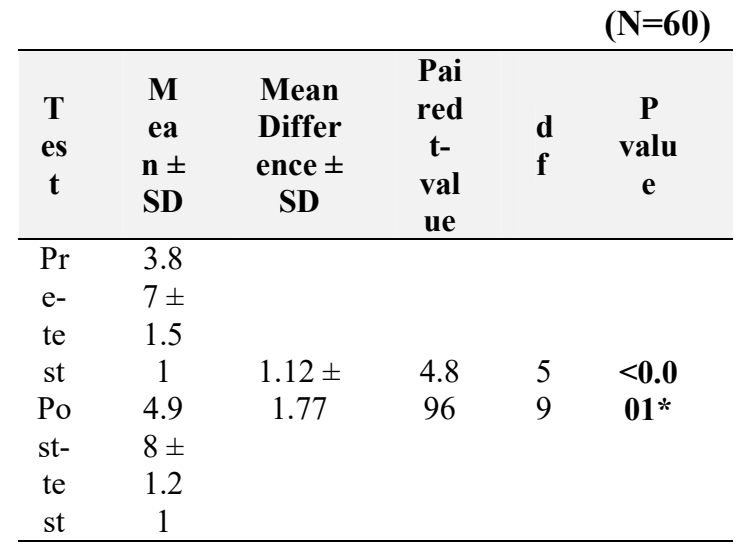

* Significant at $\mathbf{p} \leq \mathbf{0 . 0 5}$

GFNPSS-International Journal of Multidisciplinary Research, Volume 2, Issue 9, September 2021 DOI: 10.46376/IJMR/2.9.2021, P a g e 800| 45 


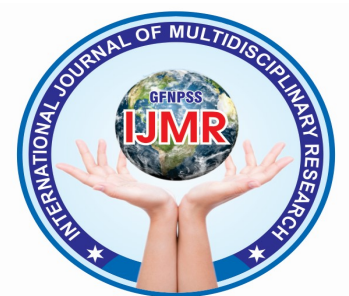

Table No. 9 shows that comparison of tertiary care hospital i.e., As knowledge the mean practice score, before and after implementation of Video Assisted Learning, the overall mean practice score was apparently higher in post-test $(4.98 \pm 1.21)$ with the mean difference of $1.12 \pm 1.77$ and the computed Pvalue for the paired t-score for is $<0.001$, which is very less than the 0.05 . Hence, there is a very highly significant difference found in between pre-test and post-test practice score regarding Bio medical waste at the level of significance $\mathrm{p} \leq 0.05$.

increases their practice also positively increases moderately.

\section{PART-VII \\ ASSOCIATION BETWEEN \\ KNOWLEDGE \& SOCIO- \\ DEMOGRAPHIC VARIABLES.}

Table No. 11: Association between Pre-test level of knowledge regarding Bio medical waste management and socio-demographic characteristic.

\section{SECTION-VI}

CORRELATION BETWEEN

KNOWLEDGE AND PRACTICE

Table No. - 10 Correlation between

knowledge and practice score

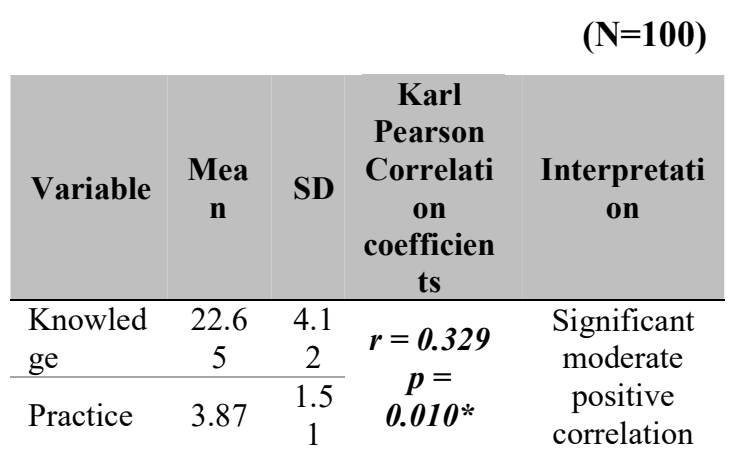

* Significant at $\mathbf{p} \leq \mathbf{0 . 0 5}$

Table no 10 shows that the calculated correlation Coefficient ' $\mathrm{r}$ ' $=0.329$ and corresponding $p=0.010$ that is very less than 0.05 , shows that there is a significant moderate positive correlation between knowledge and practice score regardingBio medical wasteamong Health Care Professionals in

GFNPSS-International Journal of Multidisciplinary Research, Volume 2, Issue 9, September 2021 


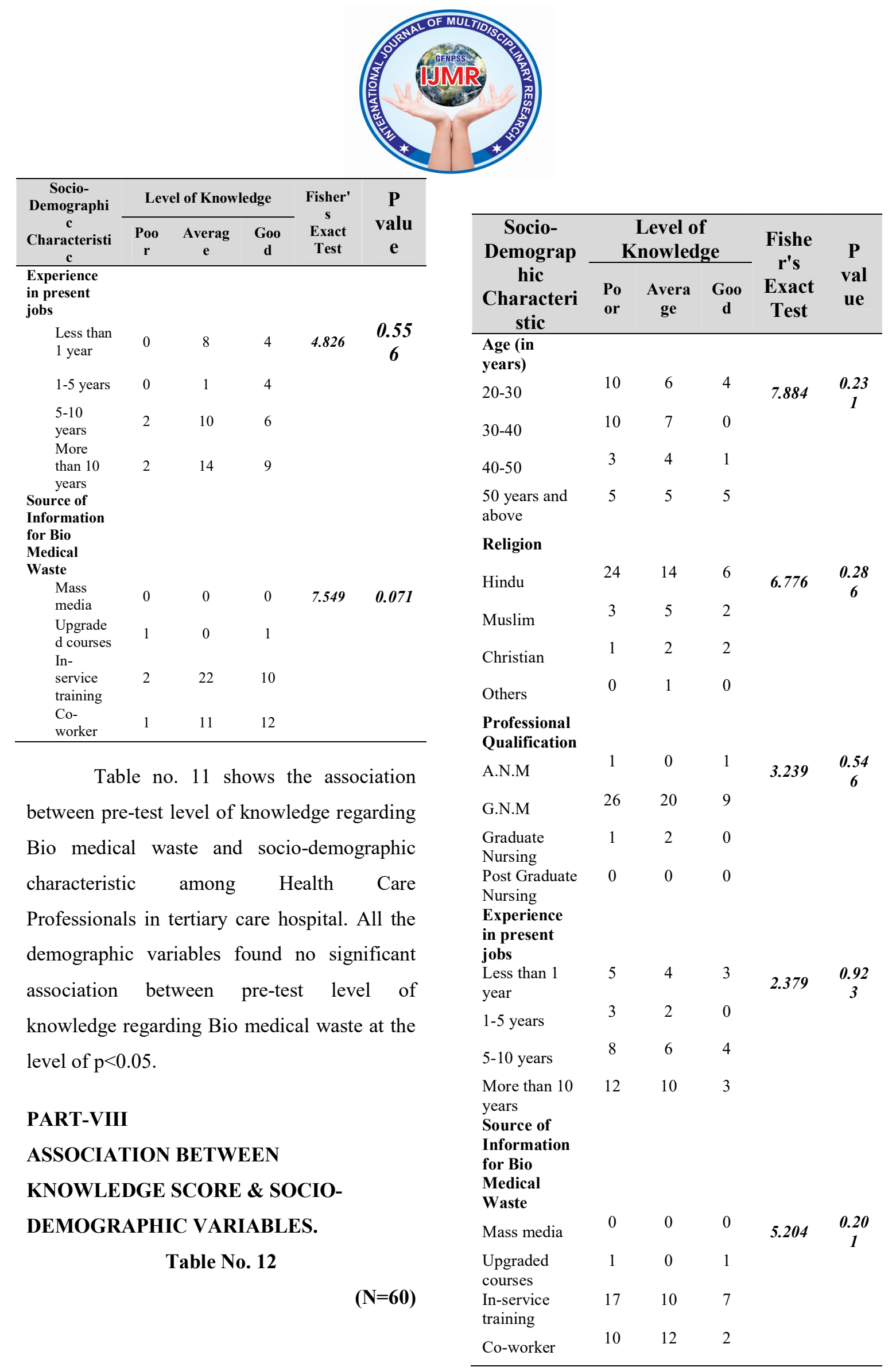

GFNPSS-International Journal of Multidisciplinary Research, Volume 2, Issue 9, September 2021

DOI: 10.46376/IJMR/2.9.2021, P a g e 802| 45 


\section{DISCUSSION}

This chapter had dealt with the analysis and interpretation of data collected from 60 Health Care Professionals in tertiary care hospital western Rajasthan at Jodhpur to assess the knowledge regarding Bio medical waste. Descriptive and inferential statistics were used for analysis.

\section{CONCLUSION:}

It was found that pre-test knowledge and practice level was poor with mean score $22.65 \pm 4.12$ and $3.87 \pm 1.51$ respectively. It was found that mean post-test knowledge score was significantly higher than mean pre-test knowledge score with mean difference of $4.43 \pm 3.94$ and computed paired ' $\mathrm{t}$ ' value was [' $\mathrm{t}$ ' ${ }_{(59)}=$ 8.721, $\mathrm{P}=<0.001]$ and mean post-test practice score was also significantly higher than mean pre-test practice score with mean difference of $1.12 \pm 1.77$ and computed paired ' $\mathrm{t}$ ' value was [ $[\mathrm{t}$ ' $(59)=$ 4.896, $\mathrm{P}=<0.001]$. It showed highly significant difference suggesting that the Video Assisted Learning was effective in increasing the knowledge and improving the practice of Health Care Professionals regarding Bio medical waste. However, all the demographic variables were found no significant association with the level of knowledge and practice regarding Bio medical waste among Health Care Professionals in tertiary care hospital.

\section{REFERENCES}

01. Government of India Ministry of Environment and forests. BioMedical Waste (Management and Handling) Rules. Gazette of India. 1998 (27 July) Available From:http://moef.gov.in/wpcontent/uploads / 2018/03/630.pdf

02. Bio-Medical Waste Management Rules. 2016 Published in the Gazette of India, Extraordinary, Part II, Section 3, Sub-Section (i), Government of India Ministry of Environment, Forest and Climate Change. Notification; New Delhi, the $28^{\text {th }}$ March, 2016.From :: https://pxmd.co/Glwl8

03. Government of India Bio-Medical Waste (Management and Handling) Rules. Gazette of India. Amendment 2018From:-https://pxmd.co/BSg3D

04.Park's Textbook of preventable social medicine; K. Park, $24^{\text {th }}$ Edition; 2019, Pp 826-831.

05. Shabeer. P. Basheer, S. Yaseen Khan, Advanced nursing practice,EMMES $\mathrm{S}, 1^{\text {st }}$ edition, Pp 335-341. 


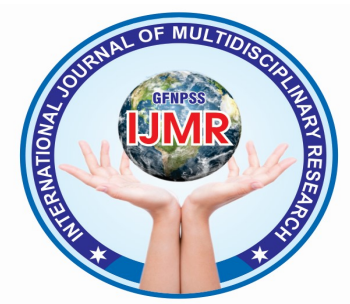

06. SwarnkarKeshav, Community health

Critical appraisal. Journal of Nursing, $2^{\text {nd }}$ edition, N.R Brothers publishers, Pp 170-184.

07. Gulani. K.K, Principles and practices, community health nursing, $2^{\text {nd }}$ edit., Kumar publishers, Pp 290-292

08. Bio medical waste (management and handling) rules; 1998 amended on 2000 by national institute health and family welfare.

09. Sharma A. Bio medical waste (Management and Handling) Rules. Suvidha Law House, Bhopal, First edition. 12.

10. Ravikant, Chitnis V, Jaiswal SP, Vaidya K, Chitnis DS. Effluent Treatment Plant: Why and How Journal of Academy of Hospital Administration. 2002; 14(1): 33-37.

11. Management of waste from Hospitals and other Health care Establishment, Euro Report and studies 1985; 1(97): 1-61

12. PriyaDatta, Gursimran Kaur Mohi, JagdishChander. BIO MEDICAL WASTE management in India:

Laboratory Physicians|Published by Wolters Kluwer-Medknow, 2018. DOI: 10.4103/JLP.JLP8917. www.jlp online.org

13. Dal Singh Kharat. Bio medical waste management rules: A review. International Journal of Advanced Research and Development. ISSN: 2455-4030, Impact Factor: RJIF 5.24: Volume 1; Issue 10; October; Page No.48-51.

14. Lalmuanpuii, Mimi, Zagade, Tuka ram, Mohite, Vaishali, Shinde, Maha deo, April 2015International Journal of Science and Research (IJSR) 909(3):1215-122 Effectiveness of Video Assisted Teaching Program Regarding Knowledge on Biomedical Waste Management among Staff Nurses

15. Authors Dr Madhvi Sanwalka, Dr Grace John Department of Pathology and Microbiology, NIMS Hospital, ted 2021 